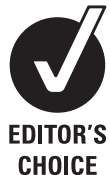

Department of GU Medicine, Nottingham University Hospitals NHS Trust, Nottingham, UK

\section{Correspondence to}

Dr Chris Bignell, Department of GU Medicine, Nottingham University Hospitals NHS Trust, City Hospital Campus, Hucknall Road, Nottingham NG5 1PB, UK; chris.bignell@nuh.nhs.uk

Accepted 10 August 2010

\title{
Azithromycin in the treatment of infection with Neisseria gonorrhoeae
}

\author{
Chris Bignell, Janet Garley
}

\section{ABSTRACT}

The efficacy of azithromycin as sole antimicrobial treatment for infection with Neisseria gonorrhoeae is reviewed. Aggregate cure rates for urethral and endocervical infection were 520/539 (96.5\%; 95\% Cl $94.3 \%$ to $97.6 \%$ ) for a $1 \mathrm{~g}$ dose from nine studies and $392 / 396$ (99\%; $95 \%$ Cl $97.5 \%$ to $99.6 \%$ ) for a $2 \mathrm{~g}$ dose from two studies. Azithromycin cured 46/47 (97.9\%) cases of oropharyngeal infection and 34/35 (97.1\%) cases of rectal infection evaluated within the clinical trials. Reports of in vitro resistance to azithromycin reveal a wide geographical spread of clinical isolates, with raised minimal inhibitory concentration to azithromycin and the emergence of high-level resistance in 2001. Concerns about resistance preclude azithromycin from general recommendation as sole antimicrobial therapy for gonorrhoea. However, azithromycin may have a valuable role in specific clinical situations and in combination with extended spectrum cephalosporins in the treatment of gonorrhoea.

\section{INTRODUCTION}

Azithromycin is an azalide derived from the macrolide class of antibiotics. It offers better oral absorption, better tissue penetration, unique pharmacokinetics and a wider spectrum of antimicrobial activity than erythromycin. The mode of action of azithromycin is inhibition of RNA-dependent peptide synthesis by binding to the $50 \mathrm{~s}$ ribosomal subunit. Azithromycin levels in tissues are up to 50 times higher than in plasma and tissue depletion half-life is 2-4 days. ${ }^{1}$ In animal studies high concentrations of azithromycin have been found in phagocytes, resulting in high concentrations of the drug being delivered to sites of infection.

Azithromycin has activity against the major bacterial sexually transmitted pathogens-notably, Chlamydia trachomatis, Neisseria gonorrhoeae, Ureaplasma urealyticum, Mycoplasma genitalium, Treponema pallidum and Haemophilis ducreyii. It is the recommended treatment for uncomplicated genital infection with $C$ trachomatis $^{2}{ }^{3}$ and seems a particularly attractive option as an oral, single-dose treatment in syndromic and epidemiological management of bacterial STIs. This paper reviews published data on the use of azithromycin as sole treatment for infection with $N$ gonorrhoeae and the growing resistance to this antimicrobial agent.

\section{AZITHROMYCIN AS TREATMENT FOR GONORRHOEA}

A Medline search was conducted using PubMed under the major headings of 'gonorrhoea and azithromycin', ' $N$ gonorrhoeae and azithromycin' and 'macrolide' and 'antimicrobial resistance.' The search was not confined to randomised controlled trials but was confined to the English language. Thirteen studies on treatment outcome were identified and reviewed. ${ }^{4-16}$ Microbiological outcome for azithromycin in the treatment of urethral and endocervical infection with $N$ gonorrhoeae is summarised in table 1 . The treatment outcome for 35 rectal and 46 pharyngeal infections is presented in table 2. Studies show considerable variation in report detail, design, size, recruitment and the proportion and definition of evaluable patients. Aggregate microbiological cure rates for urethral or endocervical infection with $N$ gonorrhoeae in the clinical trials were 392/396 (99\%; 95\% CI $97.5 \%$ to $99.6 \%$ ) for patients receiving a single $2 \mathrm{~g}$ oral dose of azithromycin and 520/539 (96.5\%; $95 \%$ CI $94.3 \%$ to $97.6 \%$ ) for patients receiving $1 \mathrm{~g}$ of azithromycin. This would suggest that the clinical efficacy of a $1 \mathrm{~g}$ dose of azithromycin fails to meet the stringent criterion for consideration in US Centers for Disease Control and Prevention (CDC) treatment guidelines, defined by Moran and Levine as a $95 \%$ cure rate with the lower level of the $95 \%$ CI exceeding $95 \%$ in summed clinical trials. ${ }^{18}$ The addition of retrospective data by Habib and Fernando ${ }^{15}$ on clinical outcome of $1 \mathrm{~g}$ azithromycin in the treatment of gonorrhoea increases the proportion cured by this dose to 688/709 (97.0\%; $95 \%$ CI $95.2 \%$ to $97.9 \%)$. Treatment efficacy was not diminished against $N$ gonorrhoeae showing in vitro resistance to penicillin, tetracycline or quinolones. Treatment failures in the reviewed studies were not generally attributable to resistance, although post-treatment sensitivities were rarely performed or cited. Where described, pretreatment isolates did not show in vitro decreased susceptibility to azithromycin. Of historical note, a failure rate exceeding $20 \%$ was observed with erythromycin in the treatment of gonococcal urethritis and failure was associated with higher minimal inhibitory concentrations (MICs). ${ }^{19}$

Most reported side effects of azithromycin are gastrointestinal. Handsfield et $a l^{4}$ reported a rate of $35.3 \%$ for gastrointestinal symptoms with a $2 \mathrm{~g}$ oral dose and this study is widely cited as rendering azithromycin untenable as a treatment for gonorrhoea. Studies using $2 \mathrm{~g}$ as a single oral dose in the treatment of syphilis report much lower rates of gastrointestinal side effects $(11.4 \%)$ and these were rated only mild to moderate and not sufficient to deter patients repeating the treatment. ${ }^{20} 21$ Side effects are either low or not reported in the other studies reviewed. Azithromycin tablets taken with food have bioequivalence to capsules taken on an empty stomach. There appears to be no data on 
Table 1 Studies reporting outcome of azithromycin treatment of Neisseria gonorrhoeae infection of the urethra or endocervix

\begin{tabular}{|c|c|c|c|c|c|c|}
\hline $\begin{array}{l}\text { Author and year } \\
\text { of publication }\end{array}$ & Participants & Study design & $\begin{array}{l}\text { Azithromycin } \\
\text { dose }\end{array}$ & $\begin{array}{l}\text { Sensitivity } \\
\text { testing to } \\
\text { azithromycin }\end{array}$ & $\begin{array}{l}\text { Bacterial cure } \\
\text { rate of } \\
\text { evaluable } \\
\text { participants }\end{array}$ & Comments \\
\hline Handsfield $1994^{4}$ & Male and female STD clinics, USA & RCT versus ceftriaxone & $2 \mathrm{~g}$ & No & $\begin{array}{l}370 / 374 \\
(98.9 \%)\end{array}$ & $\begin{array}{l}\text { Side effects reported by } 35.3 \% \\
\text { (moderate } 10.1 \% \text {; severe } 2.9 \% \text { ) }\end{array}$ \\
\hline Khaki $2007^{5}$ & Males STD clinic, New Delhi & RCT versus ceftriaxone & $2 \mathrm{~g}$ & Yes & $22 / 22(100 \%)$ & Side effects $<10 \%$ - all mild \\
\hline Lassus $1990^{6}$ & $\begin{array}{l}\text { Male and female Helsinki University } \\
\text { Central Hospital }\end{array}$ & RCT versus doxycycline & $\begin{array}{l}1 \mathrm{~g} \\
500 / 250 / \\
250 \mathrm{mg}\end{array}$ & Yes & $\begin{array}{l}20 / 20(100 \%) \\
22 / 22(100 \%)\end{array}$ & No side effects reported by patients \\
\hline $\begin{array}{l}\text { Steingrimsson } \\
1990^{7}\end{array}$ & $\begin{array}{l}\text { Males }+1 \text { female. STD clinic } \\
\text { Reykjavik }\end{array}$ & RCT versus doxycycline & $\begin{array}{l}1 \mathrm{~g} \\
500 \mathrm{mg} \times 2 \\
500 / 250 / \\
250 \mathrm{mg}\end{array}$ & Yes & $\begin{array}{l}11 / 12(91.7 \%) \\
7 / 8(87.5 \%) \\
7 / 7(100 \%)\end{array}$ & $\begin{array}{l}\text { Failure MIC } 0.125 \mathrm{mg} / \mathrm{l} \\
\text { Failure MIC } 0.5 \mathrm{mg} / \mathrm{l} \\
\text { Mild sideeffects } 8.5 \%\end{array}$ \\
\hline Odugbemi $1993^{8}$ & $\begin{array}{l}\text { Male and female STD clinics } \\
\text { Nigeria }\end{array}$ & Non-comparative & $1 \mathrm{~g}$ & No & $\begin{array}{l}114 / 120(95 \%) \\
\text { Inconsistency } \\
\text { of } \\
\text { figures in paper }\end{array}$ & $\begin{array}{l}\text { Cure = clinical }+ \text { bacteriological } \\
\text { Gastrointestinal side effects } \\
2.7 \% \text {-all mild/moderate }\end{array}$ \\
\hline Waugh $1993^{9}$ & $\begin{array}{l}\text { Male and female, STD clinic Leeds, } \\
\text { UK }\end{array}$ & Non-comparative & $1 \mathrm{~g}$ & Yes & $85 / 89(95.5 \%)$ & MIC of failures $0.25 \mathrm{mg} / \mathrm{l}$ \\
\hline $\begin{array}{l}\text { Steingrimsson } \\
1994^{10}\end{array}$ & $\begin{array}{l}\text { Males only. STD clinic } \\
\text { Reykjavik }\end{array}$ & RCT versus doxycycline & $1 \mathrm{~g}$ & Yes & $27 / 28(96.4 \%)$ & $\begin{array}{l}\text { Failure MIC } 0.125 \mathrm{mg} / \mathrm{l} \\
\text { Side effects 'negligible' }\end{array}$ \\
\hline Gruber $1995^{11}$ & Men; STD centre Rijeka, Croatia & RCT versus doxycycline & $1 \mathrm{~g}$ & No & $24 / 25(96.0 \%)$ & $\begin{array}{l}\text { No details on failure. Gastrointes- } \\
\text { tinal side effects } 4 / 66(6 \%)\end{array}$ \\
\hline Gruber $1997^{12}$ & Males and females, Rijeka, Croatia & RCT versus ciprofloxacin & $1 \mathrm{~g}$ & No & $48 / 50(96.0 \%)$ & $\begin{array}{l}\text { Gastrointestinal side effects } 4 / 50 \\
(8 \%) \text {-all mild }\end{array}$ \\
\hline Swanston $2001^{13}$ & Male and female STD clinic Trinidad & Non-comparative & $1 \mathrm{~g}$ & Yes & $\begin{array}{l}125 / 127 \\
(98.4 \%)\end{array}$ & $\begin{array}{l}\text { Failures MIC } 0.064 \mathrm{mg} / \mathrm{l} \text { and } \\
0.094 \mathrm{mg} / \mathrm{l} \text { No side effects }\end{array}$ \\
\hline Rustomjee $2002^{14}$ & $\begin{array}{l}\text { Symptomatic women. STD } \\
\text { clinic Durban, S. Africa }\end{array}$ & $\begin{array}{l}\text { RCT versus ciprofloxacin }+ \\
\text { doxycycline }\end{array}$ & $1 \mathrm{~g}$ & No & $30 / 31(96.8 \%)$ & $\begin{array}{l}\text { One failure in dual infected patient. } \\
\text { Side effects were 'few and minor' }\end{array}$ \\
\hline Habib $2004^{15}$ & $\begin{array}{l}\text { Male and female STD clinic } \\
\text { Wolverhampton, UK }\end{array}$ & Retrospective review & $1 \mathrm{~g}$ & Not stated & $\begin{array}{l}168 / 170 \\
(98.8 \%)\end{array}$ & $\begin{array}{l}\text { Failures: } 1 \text { 'due to azithromycin- } \\
\text { resistant strain'; } 1 \text { attributed to } \\
\text { vomiting soon after } 1 \mathrm{~g} \text { dose }\end{array}$ \\
\hline
\end{tabular}

MIC, minimal inhibitory concentration; RCT, randomised control trial.

whether the frequency of side effects differs between capsules and tablets. Studies rarely cite the form of azithromycin used, but a capsule preparation appears to have been used in the Handsfield study. The frequency and generally mild nature of gastrointestinal side effects should not discount the use of a $2 \mathrm{~g}$ single dose of azithromycin as treatment for gonorrhoea.

\section{RESISTANCE TO AZITHROMYCIN}

There are three main mechanisms by which bacteria acquire resistance to antibiotics: by alteration of the target site, by alteration in antibiotic transport and by modification of the

Table 2 Outcome of azithromycin treatment of rectal and pharyngeal infection with Neisseria gonorrhoeae

\begin{tabular}{|c|c|c|c|}
\hline $\begin{array}{l}\text { Author and year } \\
\text { of publication }\end{array}$ & $\begin{array}{l}\text { Azithromycin } \\
\text { dose }\end{array}$ & $\begin{array}{l}\text { Bacterial cure } \\
\text { rate of evaluable } \\
\text { participants }\end{array}$ & Comments \\
\hline \multicolumn{4}{|l|}{ Rectal infection } \\
\hline Handsfield $1994^{4}$ & $2 \mathrm{~g}$ & $26 / 27$ & \\
\hline Lassus $1990^{6}$ & $\begin{array}{l}1 \mathrm{~g} \\
500 / 250 / 250 \mathrm{mg}\end{array}$ & $\begin{array}{l}1 / 1 \\
3 / 3\end{array}$ & \\
\hline Waugh $1993^{9}$ & $1 \mathrm{~g}$ & $4 / 4$ & \\
\hline Total rectal & & $34 / 35(97.1 \%)$ & \\
\hline \multicolumn{4}{|l|}{ Pharyngeal infection } \\
\hline Handsfield $1994^{4}$ & $2 \mathrm{~g}$ & $19 / 19$ & \\
\hline Dan $2006^{16}$ & $2 \mathrm{~g}$ & $20 / 21$ & $\begin{array}{l}\text { Pre- and } \\
\text { post-treatment } \\
\text { MIC of failure } 0.5 \mathrm{mg} / \mathrm{l}\end{array}$ \\
\hline Lassus $1990^{6}$ & $\begin{array}{l}1 \mathrm{~g} \\
500 / 250 / 250 \mathrm{mg}\end{array}$ & $\begin{array}{l}1 / 1 \\
2 / 2\end{array}$ & \\
\hline Waugh $1993^{9}$ & $1 \mathrm{~g}$ & $2 / 2$ & \\
\hline Steingrimsson $1994^{10}$ & $1 \mathrm{~g}$ & $1 / 1$ & \\
\hline Manavi $2005^{17}$ & $1 \mathrm{~g}$ & $1 / 1$ & \\
\hline Total pharyngeal & & $46 / 47(97.9 \%)$ & \\
\hline
\end{tabular}

antibiotic. Selection pressures on gonococci are both antibiotic and host driven with changes occurring from spontaneous mutation and from acquisition of genes from other bacteria (horizontal gene transfer). ${ }^{22}$ Azithromycin resistance to $N$ gonorrhoeae is attributable to modification of the ribosomal attachment site and to changes in permeability and antibiotic transport. Alterations of the 23S rRNA ribosomal target by genetic mutation and by methylase-associated modification have been described. ${ }^{23-25}$ Mutations affecting the peptidyltransferase loop of domain V of $23 \mathrm{~S}$ rRNA have been described in association with high levels of azithromycin resistance. ${ }^{23} 25$ Erm genes (erythromycin ribosome methylation) encode for $23 \mathrm{~S}$ rRNA methylases and these genes can be transferred between $N$ gonorrhoeae and oral commensal Neisseria species by conjugation. $^{24}$

Efflux pumps actively export toxic compounds including antibacterial peptides and several antibiotics from the bacterial cell. In $N$ gonorrhoeae, the mtr(CDE)-encoded efflux pump is one system that exports macrolides and, while not the major mechanism, this efflux pump also contributes to chromosomal resistance to penicillin, tetracyclines and quinolones. ${ }^{26-30}$ This pump system is regulated by proteins coded by the repressor $M t R$ gene and activator $M t A$ gene. Different mutations in these controlling genes confer decreased susceptibility and low-level resistance to azithromycin. ${ }^{26-29}$

\section{EPIDEMIOLOGY OF RESISTANCE IN $\boldsymbol{N}$ GONORRHOEAE TO AZITHROMYCIN}

Monitoring trends in the antimicrobial susceptibilities of $N$ gonorhoeae has proved crucial in ensuring the appropriate recommendation of gonococcal treatment. In vitro susceptibility testing of $N$ gonorrhoeae in surveillance programmes is the principal source of data on azithromycin resistance. Resistance of $N$ 
gonorrhoeae to azithromycin is generally defined as an MIC $\geq 1 \mathrm{mg} / \mathrm{l}^{31}$ One isolate with an MIC of $2 \mathrm{mg} / \mathrm{l}$ and $\mathrm{Mtr}$ phenotype was identified among 300 strains collected in 1984 and 1985. ${ }^{32}$ The Gonococcal Isolate Surveillance Project in the USA was established in 1986, with azithromycin susceptibility testing introduced in 1992. An isolate with resistance to azithromycin was first identified in 1993 in New Mexico. ${ }^{33}$ The number of isolates with resistance has remained low in the Gonococcal Isolate Surveillance Project with 27 of 6009 (0.4\%) having an MIC $\geq 2.0 \mathrm{mg} / 1$ in 2007 . $^{34}$

Cases have been geographically scattered, with the exception of a cluster in Kansas City in 1999/2000. ${ }^{35}$ Five isolates with an MIC of $4 \mathrm{mg} / \mathrm{l}$ were identified among 91 isolates collected in Cuba between 1995 and 1998. ${ }^{36}$ Reduced susceptibility was also reported in isolates from Brazil and Caribbean. ${ }^{37} 38$ The Australian Gonococcal Surveillance Programme has been reporting since 1996 and is linked to the WHO Western Pacific Region Gonococcal Antimicrobial Surveillance Programme. These programmes report a 'low proportion of resistance to azithromycin' with no high-level resistance. ${ }^{39}$ In Europe, two isolates with an MIC of $4 \mathrm{mg} / \mathrm{l}$ were collected in Spain in 2000 to 2001. ${ }^{40}$ The Gonococcal Resistance to Antimicrobials Surveillance Programme (GRASP) was established in England and Wales in 2000. Susceptibility testing for azithromycin was added in 2001, when six of 2350 isolates $(0.3 \%)$ were found to have an MIC $\geq 1 \mathrm{mg} / \mathrm{l}$. The prevalence of resistant isolates in GRASP increased annually until 2007 when 4.1\% showed resistance to azithromycin, including six isolates with MIC $\geq 256 \mathrm{mg} / \mathrm{l}^{41}$ Resistance fell in 2008 to $0.8 \%$ with no high-level resistance identified. The European Surveillance of Sexually Transmitted Infections programme reported an overall prevalence of resistance to azithromycin of $8.2 \%(79 / 965)$ in isolates collected in 2004, with considerable variation between participating countries. ${ }^{42}$ Azithromycin resistance exceeded $9 \%$ in five of seven federal districts in Russia in 2007, with lower levels reported in $2008{ }^{43}$ Data on resistance in Africa are limited but no azithromycin resistance was identified in Lilongwe, Malawi in $2007 .{ }^{44}$

A strain of $N$ gonorrhoeae highly resistant to azithromycin (MIC > $2048 \mathrm{mg} / \mathrm{l}$ ) was isolated in Argentina in 2001 and has recently been shown to be associated with a mutation in the $23 \mathrm{~S}$ rRNA gene. ${ }^{25} 45$ More recently, high-level azithromycin resistance (MIC $\geq 256 \mathrm{mg} / \mathrm{l}$ ) has been identified in Scotland, ${ }^{46}$ England and Wales ${ }^{47}$ and Italy. ${ }^{48}$ High-level azithromycin resistance was first detected in Scotland in 2004 and was present in $33 / 845$ (3.9\%) isolates tested in $2007 .{ }^{46} N$ gonorrhoeae multiantigen sequence typing (NG-MAST) revealed that these highly resistant strains belong to a small number of sequence types. High-level azithromycin resistance emerged in England and Wales in 2007 with six isolates of the same sequence type identified. ${ }^{47}$ This outbreak is linked to high-level resistance in Scotland. No high-level resistance was detected in 2008 in GRASP. The multiclonal and geographically disparate emergence of low-level and high-level azithromycin resistance in surveillance programmes strongly argues for caution in the use of azithromycin as the sole treatment for gonorrhoea.

\section{RESISTANCE AND CLINICAL OUTCOME}

Azithromycin is not a recommended treatment for gonorrhoea and does not appear to be widely used as sole antimicrobial therapy. MICs provide an indicator as to whether resistant mechanisms are present in an isolate of $N$ gonorrhoeae. The correlation between MIC and treatment failure with azithro- mycin has not been well studied and relies on observations from clinical trials and case reports of treatment failures. In 1997 Young et al reported a case of azithromycin treatment failure with characterisation of the pre- and post-treatment isolate. The azithromycin MIC pretreatment was $0.125 \mathrm{mg} / \mathrm{l}$ and posttreatment $3.0 \mathrm{mg} / 1 .{ }^{49}$ Treatment failures in clinical trials and in a series of case reports have not shown pretreatment resistance. ${ }^{50}$ This indicates that treatment failure cannot be reliably predicted on the basis of in vitro MICs and test of cure may be advisable if azithromycin is used as the sole antimicrobial agent to treat gonorrhoea. Cases with high-level resistance identified in surveillance programmes do not appear to have received treatment with azithromycin.

If azithromycin is not sufficiently robust as a single agent in the treatment of gonorrhoea, it might potentially have a role in combination with other antimicrobial agents. Furuya et al investigated in vitro synergy between azithromycin and cefixime in 25 isolates of $N$ gonorrhoeae from male patients with urethritis in Japan. ${ }^{51}$ Significant decreases in the median MICs of both cefixime $(0.25 \mathrm{mg} / \mathrm{l}$ to $0.008 \mathrm{mg} / \mathrm{l})$ and azithromycin $(0.125 \mathrm{mg} / \mathrm{l}$ to $0.03 \mathrm{mg} / \mathrm{l})$ were observed when cefixime was combined with azithromycin. Dual treatment has been advocated for oropharyngeal gonococcal infection. ${ }^{52}$ Azithromycin may have a valuable role in combination with extended-spectrum cephalosporins to maintain treatment efficacy in the presence of the progressive increase in MICs to oral cephalosporins.

\section{SUMMARY}

The ability of $N$ gonorrhoeae to acquire resistance to antimicrobial agents is a major concern and challenge in maintaining effective treatment and control of this infection. Clinical trials of the efficacy and acceptability of azithromycin as a treatment for gonorrhoea were conducted more than a decade ago in an era when azithromycin resistance was rare. Surveillance programmes of antimicrobial resistance have clearly documented a shift in the susceptibility of $N$ gonorrhoeae to azithromycin and the emergence of high-level resistance. It has been suggested that an antimicrobial agent should not be used for the treatment of gonorrhoea when $>5 \%$ of strains demonstrate resistance. ${ }^{53}{ }^{54}$ In response to an increasing prevalence of penicillinase-producing $N$ gonorrhoeae in 1987, the CDC proposed a lower threshold of $>3 \%$ for switching treatment recommendations. ${ }^{55}$ These thresholds may not be appropriate for an antimicrobial agent such as azithromycin for which treatment failure does not seem

\section{Key messages}

A single $2 \mathrm{~g}$ dose of azithromycin has shown good efficacy in clinical trials in the treatment of infection with $N$ gonorrhoeae.

- Subsequent to clinical trials, in vitro resistance of clinical isolates has been widely described, including high-level resistance.

- Azithromycin cannot be generally recommended as a sole antimicrobial treatment for gonorrhoea but may have a role in specific circumstances or in combination therapy with thirdgeneration cephalosporins.

- Pretreatment MIC may not predict treatment outcome and test of cure should be considered when azithromycin is used as the sole antimicrobial agent for treatment of gonorrhoea. 
closely predicted by pretreatment MIC. Surveillance programmes remain crucial for updating recommendations of effective antimicrobial treatment. The history of acquisition of antimicrobial resistance to multiple classes of antimicrobial agents and the resistance data we now have on azithromycin argue against the routine use of azithromycin as single antimicrobial treatment for gonorrhoea.

\section{Competing interests None.}

Contributors CB conceived the review. CB and JG contributed to the literature review, drafted sections of the paper and edited the final manuscript.

Provenance and peer review Commissioned; externally peer reviewed.

\section{REFERENCES}

1. Sandoz Limited. SPC Azithromycin 500mg tablets. http://www.medicines.org.uk/ emc/medicine/21720/SPC/Azithromycin + 500mg + Tablets + (Sandoz + Limited)/ www.sandoz.com (accessed 8 May 2010).

2. Centers for Disease Control and Prevention. Sexually Transmitted Diseases Treatment Guidelines, 2006. MMWR 2006;55(No.RR-11):38-42. http://www.cdc. gov/std/treatment/2006/urethritis-and-cervicitis.htm\#uc4.

3. British Association for Sexual Health and HIV. 2006 UK National Guideline for the Management of Genital Tract Infection with Chlamydia trachomatis. http://www. bashh.org/documents/61/61.pdf.

4. Handsfield HH, Dalu ZA, Martin DH, et al. Multicenter trial of single-dose azithromycin vs ceftriaxone in the treatment of uncomplicated gonorrhoea. Sex Trans Dis 1994;21:107-11

5. Khaki P, Bhalla P. Sharma A, et al. Correlation between in vitro susceptibility and treatment outcome with azithromycin in gonorrhoea: a prospective study. Indian $\mathrm{J}$ Med Microbiol 2007;25:354-7.

6. Lassus A. Comparative studies of azithromycin in skin and soft-tissue infections and sexually transmitted infections by Neisseria and Chlamydia species. J Antimicrob Chemother 1990;25(Suppl A):115-21.

7. Steingrimsson $\mathbf{0}$, Olafsson $\mathrm{JH}$, Thorarinsson $\mathrm{H}$, et al. Azithromycin in the treatment of sexually transmitted disease. J Antimicrob Chemother 1990;25(Suppl A):109-14.

8. Odugbemi T, Oyewole F, Isichei CS, et al. Single oral dose of azithromycin for therapy of susceptible sexually transmitted diseases: a multicenter open evaluation. West Afr J Med 1993;12:136-40

9. Waugh MA. Open study of the safety and efficacy of a single oral dose of azithromycin for the treatment of uncomplicated gonorrhoea in men and women. J Antimicrob Chemother 1993;31(Suppl E):193-8.

10. Steingrimsson $\mathbf{0}$, Olafsson $\mathrm{JH}$, Thorarinsson $\mathrm{H}$, et al. Single dose azithromycin treatment of gonorrhoea and infections caused by $\mathrm{C}$. trachomatis an $\mathrm{U}$. urealyticum in men. Sex Transm Dis 1994;21:43-6.

11. Gruber $\mathbf{F}$, Grubisic-Greblo H, Jonjic A, et al. Treatment of gonococcal and chlamydial urethritis with azithromycin or doxycycline. Chron Derm (Roma) 1995;5:213-18.

12. Gruber $\mathbf{F}$, Brajac I, Jonjic A, et al. Comparative trial of azithromycin and ciprofloxacin in the treatment of gonorrhoea. J Chemother 1997;9:263-6.

13. Swanston WH, Prabhakar P, Barrow L, et al. Single dose (direct observed) azithromycin therapy for Neisseria gonorrhoeae and Chlamydia trachomatis in STD clinic attenders with genital discharge in Trinidad and Tobago. West Indian Med J 2001; 50:198-202.

14. Rustomjee R, Kharsany ABM, Connolly CA, et al. A randomized controlled trial of azithromycin versus doxycycline/ciprofloxacin for the syndromic management of sexually transmitted infections in a resource-poor setting. J Antimicrob Chemo 2002; 49:875-8

15. Habib AR, Fernando R. Efficacy of azithromycin $1 \mathrm{~g}$ single dose in the management of uncomplicated gonorrhoea. Int J STD AIDS 2004:15:240-2.

16. Dan M, Poch F, Amitai Z, et al. Pharyngeal gonorrhoea in female sex workers: response to a single $2 \mathrm{~g}$ dose of azithromycin. Sex Transm Dis 2006;33:512-15.

17. Manavi K, Young H, McMillan A. The outcome of oropharyngeal gonorrhoea treatment with different regimens. Int J STD AIDS 2005;16:68-70.

18. Moran JS, Levine WC. Drugs of choice for the treatment of uncomplicated gonococcal infections. Clin Infect Dis 1995;20(Suppl 1):S47-65.

19. Brown ST, Pedersen AHB, Holmes KK. Comparison of erythromycin base and estolate in gonococcal urethritis. JAMA 1977:238:1371-3.

20. Riedner G, Rusizoka M, Todd J, et al. Single-dose azithromycin versus penicillin $\mathrm{G}$ benzathine for the treatment of early syphilis. N Engl J Med 2005; 353:1236-44.

21. Hook EW, Martin DH, Stephens J, et al. A randomized, comparative pilot study of azithromycin versus benzathine penicillin $\mathrm{G}$ for treatment of early syphilis. Sex Transm Dis 2002;29:486-90.

22. Tapsall JW, Ndowa F, Lewis DA, et al. Meeting the public health challenge of multidrug- and extensively drug-resistant Neisseria gonorrhoeae. Expert Rev Anti Infect Ther 2009; 7:821-34.

23. $\mathbf{~ N g ~ L - K , ~ M a r t i n ~ I , ~ L i u ~ G , ~ e t ~ a l . ~ M u t a t i o n ~ i n ~ 2 3 S ~ r R N A ~ a s s o c i a t e d ~ w i t h ~ m a c r o l i d e ~}$ resistance in Neisseria gonorrhoeae. Antimicrob Agents Chemother 2002:46:3020-2.
24. Roberts M, Chung WO, Roe D, et al. Erythromycin-resistant Neisseria gonorrhoeae and oral commensal Neisseria spp. carry known rRNA methylase genes. Antimicrob Agents Chemother 1999:43:1367-72

25. Galarza PG, Abad R, Canigia LF, et al. New mutation in 23S rRNA gene associated with high level azithromycin resistance in Neisseria gonorrhoeae. Antimicrob Agents Chemother 2010;54:1652-3.

26. Chen PL, Lee HC, Yan JJ, et al. High prevalence of mutations in quinolonesresistance-determining regions and mtrR loci in polyclonal Neisseria gonorrhoeae isolates at a tertiary hospital in Southern Taiwan. J Formos Med Assoc 2010;109:120-7.

27. Warner DM, Shafer WM, Jerse AE. Clinically relevant mutations that cause derepression of the Neisseria gonorrhoeae MtrC-MtrD-MtrE efflux pump system confer different levels of antimicrobial resistance and in vivo fitness. Mol Microbiol 2008:70:462-78

28. Johnson SR, Sandul AL, Parekh M, et al. Mutations causing in vitro resistance to azithromycin in Neisseria gonorrhoeae. Int J Antimicrob Agents 2003; 21:414-19.

29. Zarantonelli L, Borthagaray G, Lee EH, et al. Decreased susceptibility to azithromycin and erythromycin mediated by a novel mtrR promoter mutation in Neisseria gonorrhoeae. J Antimicrob Chemother 2001:47:651-4.

30. Rouquette-Loughlin CE, Balthazar JT, Shafer WM. Characterisation of the MacAMacB efflux system in Neisseria gonorrhoeae. J Antimicrob Chemother 2005:56:856-60.

31. European Committee on Antimicrobial Susceptibility Testing. Data from the EUCAST MIC distribution website, last accessed Day Month Year. http://www. eucast.org (accessed 30 Aug 2010).

32. Slaney L, Chubb H, Ronald A, et al. In-vitro activity of azithromycin, erythromycin ciprofloxacin and norfloxacin against Neisseria gonorrhoeae, Haemophilus ducreyi and Chlamydia trachomatis. J Antimicrob Chemother 1990;25(Suppl A):1-5.

33. Ehret JM, Nims LJ, Judson FN. A clinical isolate of Neisseria gonorrhoeae with in-vitro resistance to erythromycin and decreased susceptibility to azithromycin. Sex Transm Dis 1996;23:270-2.

34. Centers for Disease Control and Prevention. Sexually Transmitted Disease Surveillance 2007 Supplement, Gonococcal Isolate Surveillance Project (GISP) Annual Report 2007. Atlanta, GA: U.S. Department of Health and Human Services, Centers for Disease Control and Prevention, March 2009. http://www.cdc.gov/std/GISP2007/.

35. McLean C, Wang SA, Hoff GL, et al. The emergence of Neisseria gonorrhoeae with decreased susceptibility to azithromycin in Kansas City, Missouri, 1999 to 2000. Sex Transm Dis 2004:31:73-8.

36. Sosa J, Ramirez-Arcos S, Ruben M, et al. High percentages of resistance to tetracycline and penicillin and reduced susceptibility to azithromycin characterize the majority of strain types of Neisseria gonorrhoeae in Cuba 1995-1998. Sex Transm Dis 2003;30:443-8.

37. Dillon JR, Rubabaza JA, Benzaken AS, et al. Reduced susceptibility to azithromycin and high percentages of penicillin and tetracycline resistance in Neisseria gonorrhoeae isolates from Manaus, Brazil, 1998. Sex Transm Dis 2001;28:521-6.

38. Dillon JR, Li H, Sealy J, et al. Antimicrobial susceptibility of Neisseria gonorrhoeae isolates from three Caribbean countries: Trinidad, Guyana and St Vincent. Sex Transm Dis 2001;28:508-14.

39. Australian Gonococcal Surveillance Programme. Annual Report of the Australian Gonococcal Surveillance Programme 2008. Commun Dis Intell 2009;33:268-74.

40. Arreaza L, Vazquez F, Alcala B, et al. Emergence of gonococcal strains with resistance to azithromycin in Spain. J Antimicrob Chemther 2003;51:190-1.

41. GRASP Steering Group. The Gonococcal Resistance to Antimicrobials Surveillance Programme (GRASP) Year 2007 report. London: Health Protection Agency, 2008. http://www.hpa.nhs.uk/web/HPAwebFile/HPAweb_C/1221117895841 (accessed 14 May 2010).

42. Martin IMC, Hoffmann S, Ison CA. European Surveillance of Sexually Transmitted Infections (ESSTI): the first combined antimicrobial susceptibility data for Neisseria gonorrhoeae in Western Europe. J Antimicrob Chemother 2006;58:587-93

43. Kubanova A, Frigo N, Sidorenko S, et al. The Russian gonococcal antimicrobial susceptibility programme (RU-GASP) - national resistance prevalence in 2007 and 2008, and trends during 2005-2008. Euro Surveill 2010;15:pii=19533. http://www. eurosurveillance.org/ViewArticle.aspx?Articleld =19533

44. Brown LB, Krysiak R, Kamanga G, et al. Neisseria gonorrhoeae antimicrobial susceptibility in Lilongwe, Malawi, 2007. Sex Transm Dis 2010;37:169-72.

45. Galarza PG, Alcala B, Salcedo C, et al. Emergence of high-level azithromycinresistant Neisseria gonorrhoeae strain isolated in Argentina. Sex Transm Dis 2009;36:787-8.

46. Palmer HM, Young $\mathrm{H}$, Winter A, et al. Emergence and spread of azithromycinresistant Neisseria gonorrhoeae in Scotland. J Antimicrob Chemother 2008:62:490-4.

47. Chisholm SA, Neal TJ, Alawattegama AB, et al. Emergence of high-level azithromycin resistance in Neisseria gonorrhoeae in England and Wales. J Antimicrob Chemother 2009;64:353-8.

48. Starnino S, Stefanelli P. Azithromycin-resistant Neisseria gonorrhoeae strains recently isolated in Italy. J Antimicrob Chemother 2009;63:1200-4.

49. Young Ho Moyes A, McMillan A. Azithromycin and erythromycin resistant Neisseria gonorrhoeae following treatment with azithromycin. Int J STD AIDS 1997;8:299-302. 
50. Tapsall JW, Shultz TR, Limnios EA, et al. Failure of azithromycin therapy in gonorrhoea and discorrelation with laboratory test parameters. Sex Transm Dis 1998;25:505-8.

51. Furuya R, Nakayama $H$, Kanayama $A$, et al. In vitro synergistic effects of double combinations of $\beta$-lactams and azithromycin against clinical isolates of Neisseria gonorrhoeae. J Infect Chemother 2006;12:172-6.

52. Sathia L, Ellis B, Phillip S, et al. Pharyngeal gonorrhoea-is dual therapy the way forward? Int J STD AIDS 2007;18:647-8.
53. Newman LM, Moran JS, Workowski A. Update on the management of gonorrhoea in adults in the United States. Clin Infect Dis 2007;44(Suppl 3):84-101.

54. Tapsall J. Antimicrobial resistance in Neisseria gonorrhoeae. Geneva, Switzerland: World Health Organisation, 2001.

55. Centers for Disease Control and Prevention. Antibiotic-resistant strains of Neisseria gonorrhoeae: policy guidelines for detection, management and control. MMWR Morb Mortal Wkly Rep 1987;36(Suppl 5):S1-18. 